\title{
Mentalist vs Behaviorist : Chomsky`s Linguistic Theory
}

\author{
Solehah Yaacob \\ Department of Arabic Language \& Literature, IRKHS, International Islamic University \\ Malaysia, 50728 Kuala Lumpur, Malaysia. \\ Tel: +0361965114 E-mail: solehah71@gmail.com
}

\begin{abstract}
The research emphasizes on the relationship between linguistics and logic according modern views and approaches. However, linguistic argumentation is needed for analyzing a language system that uses the meaning of expressions in a sentence to provide the complete meaning of the sentence, as there lies a dependence between expressions. In fact, the connection between expressions enhances the overall meaning from the fundamentals of the sentence structure in the logical relationship between ideas; where there lies a relation between words and thought, which is dependent on the logic of combined utterances. In order to signify the above concept of thinking, the researcher has reviewed the theory of the early system of Arabic grammar that focuses more on an analogical approach rather than anomaly. The analogical approach in the system is based on the underlying theory that implies the aforementioned relationship, even though some modern views may disagree on the interpretation of this issue. To add to the discussion, the researcher has included similar existing theories on Chomsky's approaches, which have shown the logical approach as a result from the connection between linguistic argumentation and logic. As a result of this discussion, the connection between words and logic is shown to be a universal concept.
\end{abstract}

Keywords: Logic; Method; Descriptive Grammar; Mentalist; Behaviorist

\section{Introduction}

Descriptive Grammar posed extreme criticism to Traditional Grammar, especially regarding the mental perceptions which it represents, [and this often being Aristotle's approach in logic]. Chomsky was raised in a school that applies the Bloomfield approach in Linguistic Research, that is, emphasis on the scientific basis of linguistics and an adherence to behaviorism. Despite the stability and growth of this school, Chomsky directed hard criticism towards it and towards Descriptive Grammar in general. The first half of the 20th century was marked by the structuralist school, based on the work of Ferdinand de Saussure in Europe and Edward Sapir and Leonard Bloomfield in the United States. Bloomfield was the most concerned [amongst linguists] that linguistics was "scientific" and "autonomous". Thence, he had struggled in eliminating all that he viewed as invalid for an accurate, descriptive science [that uses/requires precise information systems]. On the other hand, the influence of Anthropology on Sapir [within Descriptive Grammar] made his concept [and perception] towards language more human; hence, his focus was on its cultural importance (i.e. on how cultural patterns were shaped). The need for the linguistic research to be "scientific" made Bloomfield reject all materials that were not subject to direct observation, as well as to the natural (physical) measurement, and this was followed in the ideology of behaviorism, as previously mentioned. From this, he confirmed that studying the "thought" is the weakest point in linguistics, and he tried eliminating it from the research scope and attempted at its limitation to Phonology and systems on a formal basis.

\section{Chomsky`s Critique on Descriptive Grammar}

Chomsky rejected this as he saw that linguistic research is focused on the description of the linguistic surface, as it is, in the standards of stimulus and response [as behavior/actions] i.e. the linguistic research almost treats a human 
as a "machine" that moves according to rules determined by certain [preset] situations. The linguist simply has to determine these specific procedures to reveal or uncover this human behavior. [This is the idea of behaviorism.] Generally, descriptive grammar, and as specifically represented by Bloomfield's school, only presents these formal modes through "discovery procedures" as Chomsky had named them (Chomsky, 1957). This means that the idea of autonomy of the linguistic study and its "scientificness" does not actually present anything connected to the man by considering him human, rather, it falls under the dominance of the scientific idea, towards the automated description in fear of falling under Metaphysical interpretations.

On the hand, Chomsky's perception of human beings is deep and less mechanical. The human being, according to Chomsky, is not a machine, he does not differ from an animal except in his ability to think and his intelligence, but more importantly, he differs in his linguistic ability. Without a doubt, language is the most important aspects of human activity. It is illogical to possess this important ability and then [for it] to be converted to mere formal structures where the followers of Descriptive Grammar strive for its divestiture from "thought" and from the mind, this superficial description was provided by De Saussure at the beginning of the $20^{\text {th }}$ century. Studying a language as Chomsky sees it should not stop at this descriptive approach by considering it autonomous, it does not exceed the limits of the direct subject, and what is important in this linguistic study helps us to understand human nature. Chomsky particularly draws the attention towards children. For example, at the age of five a child can pronounce hundreds of sentences every day, sentences that they have not said or known before, and they can understand words that they have not heard before. [Where did these come from? Therefore, Chomsky views that there has to be something deeper to the subject and that the 'action-reaction-repetition' does not explain this ability in children.] This implies that there are deep origins [and processes] in the human structure that distinguishes man from other creatures. These deep origins in the human being are yet to be discovered. Chomsky views that there are common or universal values in all human languages; he believes that these value can determine biology as it forms part of our human nature (Yaacob, 2013, Yaacob 2014a).

Ibn Khaldun, who presented his psycholinguistic theories in al-Muqaddimah, in the $14^{\text {th }}$ Century, also divided the linguistic ability into competence, performance, meaning and situation. We can see that Chomsky uses these terms in a similar manner, however, he also distinguishes between syntax and meaning. Therefore, the linguist first has to consider the human being's language ability. Accordingly, the description of surface structure does not present anything; it is not even considered a science because it does not explain anything, the most important is that we have to realize that the "deep or underlying structure" is the laws of human nature. Chomsky sees that there are substantial differences between human beings, animals and machines. Scientists should consider these differences and all factors that weaken the foundations of descriptive linguistics. Since the issue of its autonomy is meaningless, it is inevitable to use philosophy and psychology as an essential aid. For this reason, Chomsky saw that what we need is a linguistic theory that participates in the understanding of human nature with the consideration of scientific principles.[Based on the above, we can thus add that Chomsky is a mentalist who believes in 'thought' and 'mind', even if such studies are not easy to verify.]

\section{The Linguistic Theory and its Goals}

The most important thing that differentiates Chomsky is perhaps his efforts to establish a general (universal) theory for a language to originate from a mentalistic dimension. This dimension started dimly at the beginning in his first writings and then developed into the foundation of the whole approach, this 
mentalistic theory in its essence is built on what can be called "infiniteness of language". He holds that each language is composed of a limited group of sounds and writing symbols that produces or generates infinite sentences. He said:

"From now on I will consider a language to be a (finite or infinite) set of sentences, each finite in length and constructed out of a finite set of elements. All natural languages in their spoken or written form are languages in this sense, since each language has a finite number of phonemes (or letters in its alphabet) and each sentence is representable as a finite sequence of these phonemes (or letters), though there are infinitely many sentences." (Chomsky, 1972).

Based on the statement, we can understand that each and every language in this world has a set of finite and infinite components, and finite components focus on the phoneme that is limited (smallest sound unit that can convey a distinct meaning). We form meaningful morphemes (smallest unit of language that has meaning) from these finite components. If this is the case, then the language is creative by its nature. In other words, each speaker can say sentences that no one had ever spoken before, and is able to understand sentences that he had never heard before. Hence, linguistic theory has to be able to determine how to produce sentences that are infinite from finite sound elements. This theory is directed towards the native speaker, or to what Chomsky calls the Ideal speaker-hearer, in a homogeneous linguistic society that has complete knowledge of his language. This is necessary because the aim is to acknowledge the language capability that makes humans special. To achieve this purpose, Chomsky rejects the descriptive grammar that stands on linguistic facts as presented by the field research in its actual forms, and confirms that there are two aspects that need to be focused on in order to understand the human language. The first aspect is the actual linguistic performance that represents a human's pronunciation, while the second aspect is the underlying competence of the ideal speaker-hearer, this aspect represents the deep structure of speech. These two terms, performance and competence, form the cornerstone of the linguistic theory. According to Chomsky, the performance or the surface reflects the competence i.e. it reflects the occurring processes in the depth. This means that the language we speak actually has several deep mental processes, disappearing behind the consciousness, or sometimes behind the subconscious; and studying the performance, which is the surface structure presents the phonetic explanation of the language, as for studying the competence, which is depth structure presents its semantic interpretation (Chomsky, 1972). The theory described above requires a linguist to consider what the followers of Descriptive Grammar used to reject from the traditional grammar, for it was a normative based grammar examining what is correct in language. However, studying the performance and capability must seek what Chomsky calls grammaticality in language, i.e., the rules on which a sentence is deemed acceptable to a linguist. This means that the aim of grammar is to differentiate between what is grammatical and what is not grammatical in language, which means that grammar organizes all grammatical sentences. "The fundamental aim in the linguistic analysis of a language $\mathrm{L}$ is to separate the grammatical sequences which are the sentences of $\mathrm{L}$ from the ungrammatical sequences which are not sentences of $\mathrm{L}$ and to study the structure of the grammatical sequences" (Chomsky, 1957). The basic target is to get the correct language, which can be achieved by utilizing Chomsky's theory as explained above. We will not be delving into deep details of Chomsky's theory, but we will be addressing the grammatical acceptance of a sentence that requires more than the dictionary's meaning. It relies on a deep system possessed by the speaker by which he can differentiate between one sentence and another. It might be suitable to provide some examples of what Chomsky presented to clarify this idea. If we look at the following two sentences (grammatical of sentences (Language of L) 
and ungrammatical sentences (not sentences of $\mathrm{L}$ or not Language of $\mathrm{L}$ ), we will notice that they both do not indicate the meaning but a native English speaker would feel that the first sentence is grammatical and the second is ungrammatical because the surface structure of the first coincides with the laws of the deep structure. The understanding of Chomsky's theory clarifies the essential difference between him and the followers of Descriptive Grammar. According to Chomsky, grammar should consider the intuition of the speaker because he is not a machine that produces sounds in response to external factors; rather he is influenced by internal factors. Hence, intuition is not a secondary element in a linguistic study but rather a substantial element. When intuition is humanly, the theory therefore, as we have mentioned, is seeking knowledge about the overall phenomena in each language. This does not mean that these phenomena or occurrences can be found in all languages, but it can be studied separately from a certain language, as we have seen in what is known as distinctive features of Phonology (Schane, 1973), which is now necessary to understand the phonological phenomena in all languages. It also contradicts the descriptive doctrine that every language is a law in itself. Chomsky being subscribed to rationalist theories views that the human mind is the means of knowledge; as opposed to the followers of Descriptive Grammar who belong to the empiricists, those of whom believe that we arrive at knowledge by way of experiments. This is the linguistic theory according to Chomsky in its general headlines; we will address some of its aspects in the next chapter, but what are the origins of the theory that had a profound impact in converting the linguistic study to what is known now in the American universities.

The relationship between language and logic was discovered by early Muslim scholars (Yaacob, 2014b). They believed that drawing a relationship between the two was basically a rouse to redirect the topic of discussion to theology and law in terms of Aristotelian logic. However, in order to claim this argument and to exhibit the relevance of logic for the study of grammar, we will henceforth use the term 'linguistic argumentation' to refer to the study of the Arabic grammar system. In fact, AlFarabi (d.950) developed such a theory on the relationship between language and logic, discussing the origin and development of language from a logician's point of view. This can be found in his book Kitab al-huruf(Al-Farabi, 1996a; Zaidan, 1984) wherein he connects the ideas of Arabic grammar, demonstrating his awareness of the relevant differences between languages, in general, and between Greek and Arabic, in particular (Veerstegh, 1977). His aim was to incorporate the disciplines of grammar and logic, for he believed, without a doubt that they were connected to each other. He based this on his view that the use of logic transcends the domain of any particular language and is common to all languages (Al-Farabi, 1996a). Here he explained the connection between language and logic concerning the expression of a particular linguistic group or nation that is related to their mode of expressing meaning in a grammatical sense, and that the expression of all nations or logics demonstrates an approach of universality, which is a valid means of expression for all nations. This point has been supported by, Ikhwan al-Safa, The Brethren of Purity, in their Rasa 'il. They believed that the heart is the organ responsible for distinguishing between intelligible (mafhum), and unintelligible sounds. From the former, it distills the meaning ( $\mathrm{ma}^{\text {'ani) }}$ of sounds. They regarded this as the process of knowledge in establishing a correspondence between word and meaning (Ikhwan al-Safa, 1995). The Brethren of Purity are not the only scholars to have discussed the corresponding relationship between the issue of word, meaning and thought, Jabir Ibn Hayyan (Veerstegh, 1977) also has a speculation about the correspondence between word and meaning where he believed this correspondence is based on the balance of letters (Mizan al-Hurüf). This theory is clearly derived from Greek sources and is based on concepts ranging from the numerical speculations of the Pythagoreans to Plato's dialogue on Kratylos (Sambursky, 1959) 
postulation on the origin of language. However, Ibn Hayyan places greater interest on the nature of physical elements in his investigation. Thus, he often uses grammatical theory as a heuristic instrument such as the grammarian applies his methods of Tasrif (morphology) in order to determine their radicals in contrast the alchemy or physical scientist dissects the objects in order to find out their constituent element (Veerstegh, 1977). The discussion on the origin of language by Ibn Jinni and his teacher, Ibn Faris, should also be considered for his arguments on the origin of language being revelation or agreement between word, meaning and thought. Notably, most of the speculative philosophers held that the connection between language and logic is a matter of mutual agreement and convention rather than revelation and inspiration. This statement emphasizes the human nature of language and origin of speech. Based on this concept, arises the Mutazilite correlation that since man has free will, then men are responsible for their own acts, their own words. In the context of the spoken word, man he is the one who brings into being, such as the nomenclature of mutakallim can be given only to someone who produces speech (Ibn Jinni, 1952, Yaacob, 2015). This leads to the discussion of the literary study conducted by al-Jurjani regarding meaning and expression, he considered the logical ideas to be signified by the expression. He linked his view to meaning as being the determining factor, distinguishing the level of quality of linguistic dimension in a text; by not considering this dimension in isolation but rather as it is realized within a coherent text (Al-Jurjani, 1960).

\section{Conclusion}

From the aforementioned viewpoints, it is relevant that the relationship between language and logic is not a matter of philosophical speculation discussed among philosophers, but it's also been a field of study and discourse between grammarians and rhetoricians. Meant, the Chomsky`s views in linguistic approaches has been discussed among Arab grammarians, rhetoricians and Muslims'philosophers, however the sophisticated approach has been done which cannot be regardless.

\section{References}

Al-Farabi. (1953). Kitab 'Ihșa' al-Ulum (A. G. Palencia, Trans.). N.P, Spain, Madrid.

Al-Farabi. (1996a). Kitab al-Huruf. M. Mahdi (Ed.). Dar al-Mashriq, Beirut, Lebanon.

Al-Farabi. (1996b). Kitab 'Ihșa' al-Ulum. Dar wa Maktabat al-Hilal, Beirut, Lebanon.

Al-Jurjani, A. Q. (1960). Dalail al-I’jaz. S M. R. Redha (Ed.). Maktabah Muhammad Ali Subaih wa Awladuhu, Egypt, Cairo.

Chomsky, N. (1957). Syntactic Structures. Monton \& Co, Netherlands, The Hague.

Chomsky, N. (1972). Aspects of the Theory of Syntax ( $8^{\text {th }}$ ed.). MA The M.I.T Press, USA, Cambridge.

Ahmad Abdul, R. H. (1985). Al-Alaqah Baina al-Lughah wa al-Fikri: Dirāsah al-Luzumiyyah Baina al-Lughah wa al-Fikri. Dar al-Ma`arifah al-Jami’ah, Egypt, Alexandria.

Ibn Jinnī. (1952). Al-Khasois (Vol. 1). A. H. Muhammad (Ed.). Dar al-Kutub al-Arabiyah, Beirut, Lebanon

Ikhwan al-Ṣafa. (1995). Rasa'il Ikhwan alȘafa wa Khalan al-Wafa (Vol. 1). Mansyurat Uwaydat, Beirut, Lebanon.

Sambursky, S. (1959). A Democratean Metaphor in Plato's Kratylos. Journal for Ancient Philosophy, 4(1), 1. Retrieved from http://www. jstor.org/stable/418164

31.3.2013

Schane, S. (1973). Generative Phonology. Prentice Hall Foundations of Modern Linguistics, Englewood Cliffs, USA, New Jersey. 
Veerstegh, K. (1977). Landmarks in Linguistic Thought 111. Routledge, England, London.

Yaacob, S. (2013). Linguistic Argumentation and Logic: An Alternative Method Approach in Arabic Grammar. Argument: Biannual Philosophical Journal, 3(2), 407- 430.

Yaacob, S. (2014a). Alternative Paradigm For Language Acquisition, publication in Open Journal of Modern Linguistics, Scientific Research Publication, 4(3), 465-469.

Yaacob, S. (2014b). Kefahaman Nahu Arab Dan Sejarah Perkembangannya Dalam Menentukan Penggunaan Kalimah Allah, e-Journal Language Practice and Information Technology 2014, 1, 9-11. Retrieved from: http://worldconferences. net/journals/glit/toc/index.html.

Yaacob, S. (2015). Mauqif al-Mustasriqin Min al-Lughah al-Arabiyyah, Arab Journal For The Humanities, Kuwait University, Academic Publication Council, 33(129), 11-37.

Zaidan, M. F. (1984). Fi al-Falsafah al-Lughah. Dar al-Nahḍah al-Arabiyah, Beirut, Lebanon. 